\title{
Studi Peluang Pengembangan Ekowisata Untuk Mendukung Keberlanjutan Kota (Studi Kasus: Kelurahan Medokan Ayu, Surabaya)
}

\author{
Wiwik Dwi Susanti ${ }^{1 *}$, Muchlisiniyati Safeyah ${ }^{1}$, Fairuz Mutia $^{1}$ \\ ${ }^{1}$ Lab Perancangan Kawasan dan Bangunan Arsitektur, Progdi Arsitektur, Fakultas Arsitektur dan Desain, UPN “Veteran” Jawa Timur \\ *Email: wiwikds.ar@upnjatim.ac.id; Telp. +62 852-228-677-289
}

\begin{abstract}
Abstrak:
Kegiatan pariwisata harus mampu menjaga dan mengedapankan kelestarian lingkungan, memperhatikan kondisi sosial dan perekonomian masyarakat. Seharusnya kegiatan pariwisata harus mampu menjaga keseimbangan alam sekitar tidak hanya mempertimbangan keuntungan secara ekonomi saja. Ekowisata adalah kegiatan wisata alam dengan mempertimbangkan unsur pendidikan, dan upaya konservasi sumberdaya alam, serta mendukung perekonomian masyarakat. Ekowisata dianggap sebagai salah satu solusi untuk mendukung keberlanjutan kota yang meliputi 3 aspek yaitu lingkungan, ekonomi dan sosial. Medokan Ayu merupakan salah satu Kelurahan di Kota Surabaya yang lokasinya berdekatan dengan pesisir Timur. Wilayahnya berupa tambak, mangrove dan permukiman. Tambak di Medokan Ayu menghasilkan ikan Bandeng terbaik di Surabaya. Sehingga Medokan Ayu memiliki banyak potensi (wisata tambak, kuliner dan wisata mangrove) yang bisa dikembangkan untuk mendukung konsep ekowisata. Penelitian ini berusaha untuk mengkaji peluang Kelurahan Medokan Ayu untuk dapat dikembangkan menjadi ekowisata sebagai pendukung keberlanjutan kota. Penelitian ini dapat dipetakan potensi yang dapat dikembangkan menjadi ekowisata dan dapat memberikan keuntungan bagi warga sekitar dan mendukung keberlanjutan Kota Surabaya. Hasil analisa diketahui bahwa potensi (aspek fisik dan non fisik) yang dimiliki Medokan Ayu mampu dikembangkan menjadi ekowisata yang mendukung keberlanjutan kota.
\end{abstract}

Kata Kunci: ekowisata; Medokan Ayu; bandeng; kampung hidroponik; mangrove

\section{Latar Belakang}

Ekowisata atau wisata yang lebih mengedepankan pelestarian terhadap lingkungan alam dengan dikelola secara alami dan juga mengedepankan aspek pendidikan bagi pengunjungnya. Keindahan alam lebih ditonjolkan untuk dapat menarik kunjungan wisatawan. Selain pendidikan unsur konservasi dan juga upaya untuk mendatangkan keuntungan bagi masyarakat sekitar baik dari aspek finansial dan juga lingkungan (Suprayitno, 2008). Pemerintah Indonesia sejak tahun 2002 telah menetapkan konsep ekowisata sebagai salah satu langkah untuk pariwisata keberlanjutan (Rakor Bidang Perekonomian, 2002). Keputusan untuk mengembangkan konsep ekowisata di Indonesia upakan salah satu upaya untuk meningkatkan kualitas lingkungan, memberdayakan tenaga kerja lokal dan juga untuk meningkatkan kesejahteraan masyarakat setempat. Tetapi dalam kenyataannya, konsep ekowisata di Indonesia masih banyak menemui permasalahan. Permasalahan itu berkaitan dengan konsep penting dari ekowisata, proses pengembangan produk yang dihasilkan oleh ekowisata dan juga berbagai dampak di masyarakat (Atmoko, 2008).

Kelurahan Medokan Ayu merupakan satu kelurahan di Kecamatan Rungkut yang memiliki banyak potensi ekowisata untuk lebih dikaembangkan lagi. Dalam pengembangannya diperlukan kajian atau studi untuk melihat potensi tersebut. Kondisi geografis yang beragam menjadikan Kelurahan Medokan Ayu memiliki wisata alam, budaya dan kuliner. Wisata alam berupa wisata mangrove yang pengelolaanya dilakukan oleh Pemkot Surabaya. Untuk mengembangkan kawasan ekowisata mangrove Gunung Anyar harus disesuaikan dengan konsep konservasi yaitu untuk pengendali banjir Kota Surabaya dan juga sebagai konservasi flora dan fauna asli di kawasan mangrove. (Soegianto, 2007). Kampung hidroponik merupakan wisata buatan yang sekaligus dikolaborasikan dengan unsur alam dengan memanfaatkan aliran sungai. Sedangkan wisata kuliner dan tambak bandeng juga menjadi salah satu wisata yang dapat dikembangkan dengan mengkolaborasikan antara wisata budaya dan alam. Melihat potensi tersebut, maka pada penelitian ini berupaya untuk mengidentifikasi ketiga wisat tersebut dalam kerangka ekowisata. Dimana ekowisata ditekankan pada pelestarian alam dan pemberdayaan masyarakat. Harapannya dengan mengetahui potensi tersebut maka dapat memberikan gambaran mengenai prospek wisata tersebut guna mendukung keberlanjutan kota. 


\section{Metode}

Jenis penelitian yang digunakan dalam penelitian ini adalah penelitian diskriptif yaitu penelitian yang dilakukan untuk mendapatkan gambaran atau penjelasan tentang suatu fenomena.

\subsection{Metode Pengumpulan Data}

Metode pengumpulan data yang digunakan pada penelitian ini yaitu pengumpulan data primer dan pengumpulan data sekunder. Pengumpulan data primer dilakukan dengan teknik observasi langsung yang kemudian dilengkapi dengan teknik wawancara. Observasi dilakukan pada seluruh RW di Kelurahan Medokan Ayu yang meliputi pengamatan dari aspek tangible dan intangible. Aspek tangible meliputi kondisi lingkungan sekitar (Potensi alam dan juga lingkungan binaan) sedangkan aspek intangible meliputi aspek social, budaya dan tradisi di kelurahan Medokan Ayu.

Sedangkan data sekunder melalui studi pustaka yang terkait dengan teori ekowisata dan perancangan kota. Studi pustaka meliputi jelajah jurnal dan buku sehingga dapat dilihat posisi keilmuannya.

\subsection{Metode Analisis Data}

Teknik analisis data dalam penelitian ini menggunakan analisis deskriptif kualitatif dan analisis SWOT. Rangkuti (2013) metode analisii SWOT adalah salah satu metode yang digunakan untuk menganalisa kekuatan (strengths), peluang (opportunities), kelemahan (weaknesses) dan ancaman (threats) secara sistematis dan juga terperinci.

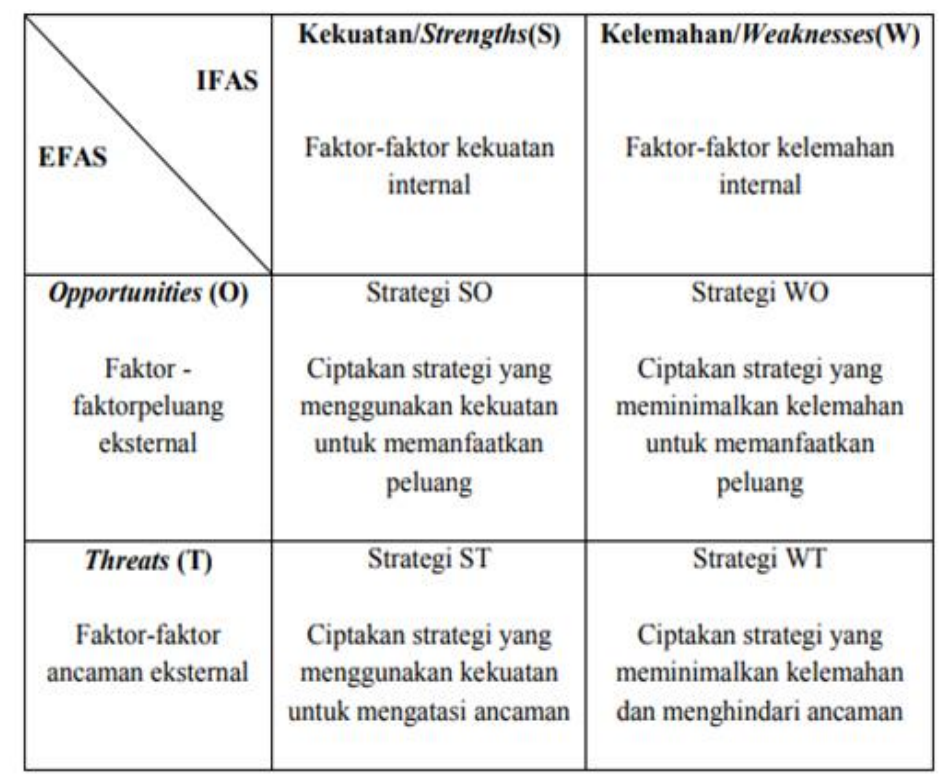

Gambar 1 Diagram SWOT

\section{Hasil dan Pembahasan}

\subsection{Gambaran lokasi penelitian}

Kelurahan Medokan Ayu merupakan salah satu kelurahan yang lokasinya berada di pesisir Timur Kota Surabaya. Secara geografis Kelurahan Medokan Ayu merupakan area permukiman, rawa dan tambak. Kelurahan Medokan Ayu memiliki luas: 728 Hektare dan jumlah Penduduk: 16.369 jiwa yang memiliki karekter penduduk yang beragam. Salah satu potensi alam yang dimiliki oleh Kelurahan Medokan Ayu yaitu potensi tambak.

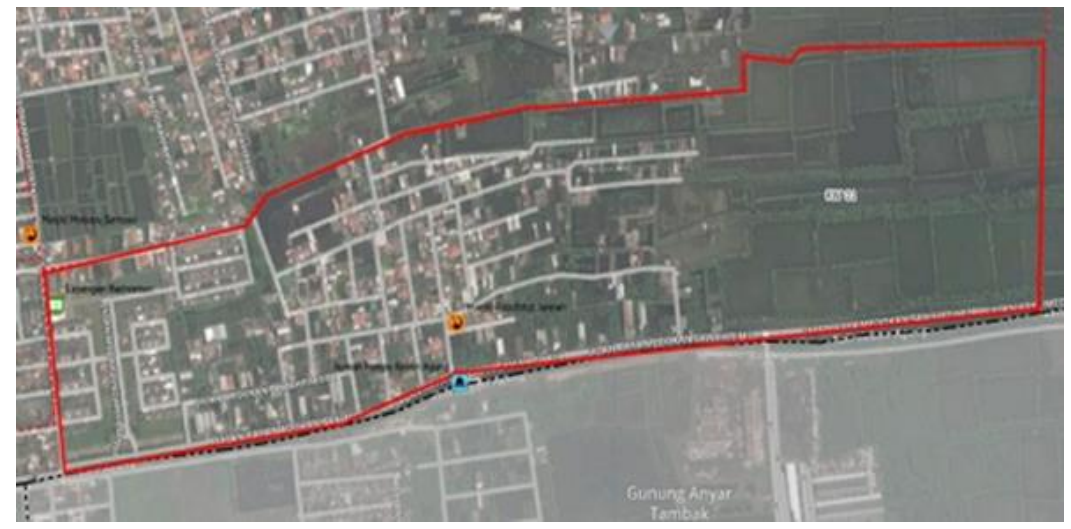

Gambar 2 Peta Kelurahan Medokan Ayu 


\subsection{Jenis-jenis Ekowisata}

Menurut Yoeti (1997), jenis ekowisata berdasarkan objek terbagi menajdi dua jenis, yaitu:

1. Ekowisata alam.

Pada Kelurahan Medokan Ayu terdapat 2 wisata yang masuk dalam golongan ekowisata alam yaitu wisata kampung hidroponik dan wisata mangrove.

- Wisata kampung hidroponik

Kampung hidrop onik di Kelurahan Medokan Ayu tepatnya berada di RW XII. Kampong hidroponik telah mampu memberikan oase ditengah lingkungan padat penduduk di kota Surabaya. Kampung ini merupakan upaya dari warga sekitar yang memiliki kesamaan hobby untuk menjadi petani hidroponik. Bekerjasama dengan Bank Swasta kampung hidroponik di Medokan Ayu ini menjadi lebih banyak pengembangannya dalam bertani hidroponik. Tidak hanya sayuran tetapi buah-buahan juga ditanam dengan system hidroponik. Kampung hidroponik nantinya akan dikolaborasikan dengan memanfaatkan aliran sungai sebagai salah satu alternative dalam menikmati berwisata hidroponik.
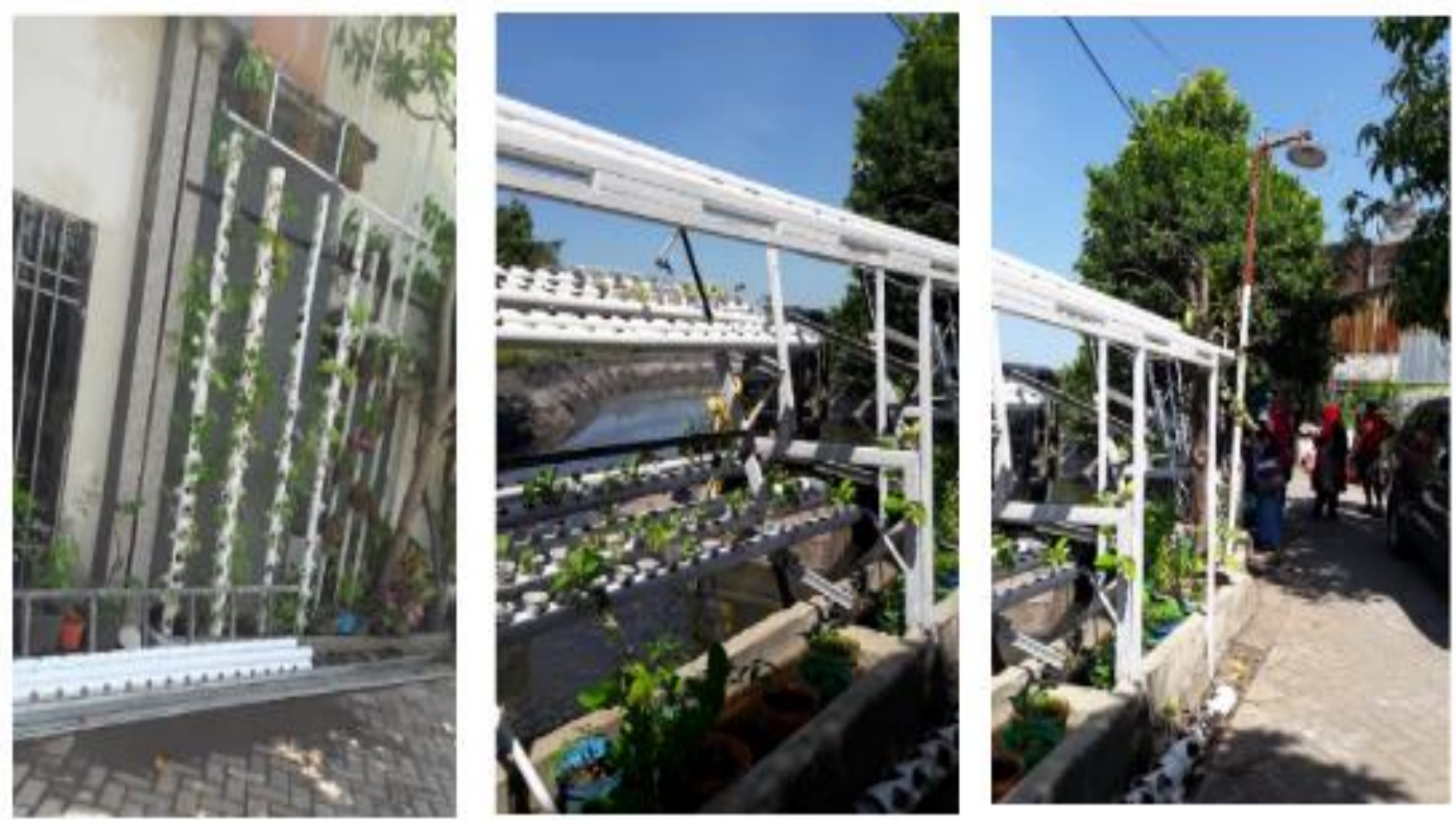

Gambar 3 Kampung Hidroponik

- Wisata mangrove

Medokan Ayu merupakan salah satu kelurahan di Kecamatan Rungkut yang berbatasan langsung dengan area konservasi hutan mangrove disisi sebelah Timur Surabaya. Wisata mangrove merupakan salah satu wisata alam yang lokasinya berada pada area konservasi Pemkot Surabaya. Wisata ini berusaha untuk menyajikan potensi alam dan fauna mangrove yang masih alami. Wisatawan diajak menikmati tambak yang juga ditumbuhi oleh pohon mangrove yang masih sangat alami. Dominasi wisata yang disajikan yaitu wisata alam yang sekaligus wisatawan diajak untuk belajar aneka jenis pohon mangrove dan aneka satwa asli mangrove. 

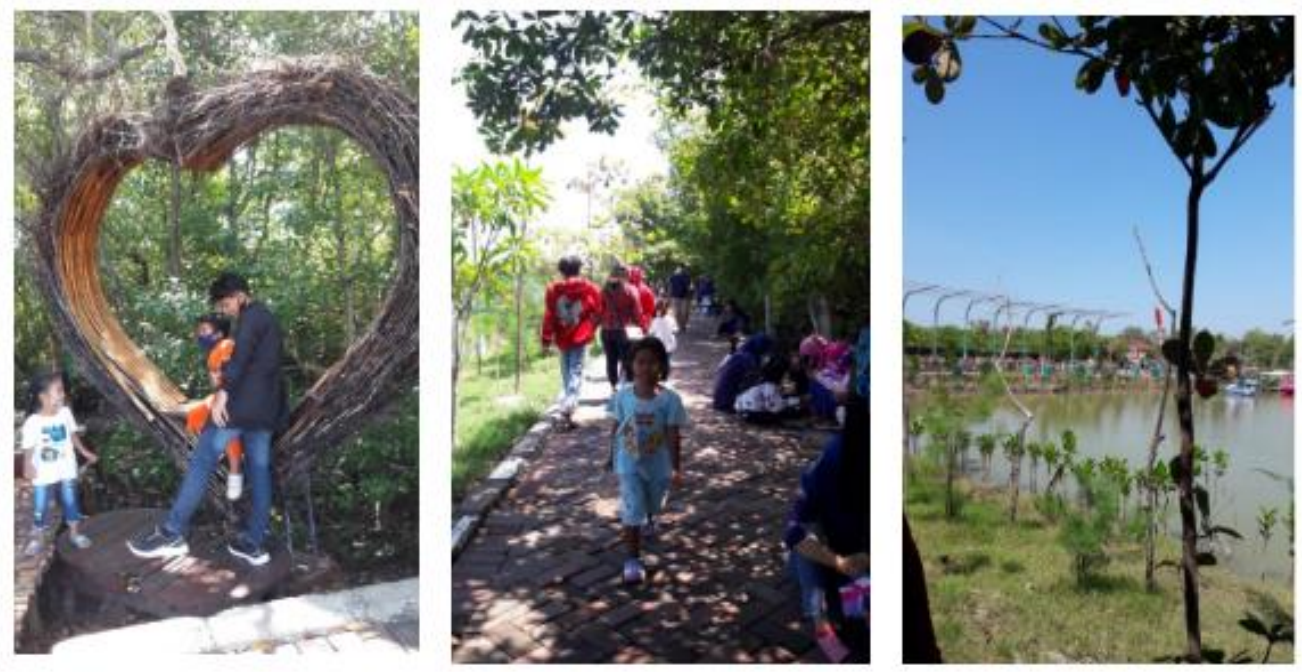

Gambar 4 Wisata Mangrove

\section{Ekowisata budaya.}

Ekowisata budaya yaitu ekowisata yang menekankan pada hasil budaya dari suatu daerah yang bisa dilihat dan dipelajari sebagai bagian dari pendidikan.

- Wisata bandeng

Medokan Ayu merupakan salah satu Kelurahan di Surabaya yang memiliki potensi sebagai penghasil bandeng. Bandeng yang dihasilkan di Medokan Ayu merupakan bandeng asli dari tambak warga. Kelebihan dari bandeng yang dihasilkan di Medokan Ayu adalah dagingnya yang empuk dengan teksture yang lembut dan warna yang ayu (cantik) (Cak Sur, 2011). Produk-produk olahan bandeng juga dipasarkan oleh warga Medokan Ayu mulai dari bandeng asap, otak-otak bandeng dan bandeng sapit. Potensi tersebut bisa dikembangkan menjadi wisata tambak dan juga wisata kuliner yang tetap mengedepankan konsep ekowisata. Kuliner bandeng dan tambak bandeng menjadi bagian dari budaya warga Medokan Ayu karena berkaitan dengan ciri khas dan kebiasaan yang pada akhirnya menghasilkan identitas. Sehingga yang lebih ditonjolkan pada wisata bandeng adalah aspek budaya yang kemudian dikolaborasikan dengan aspek alam.

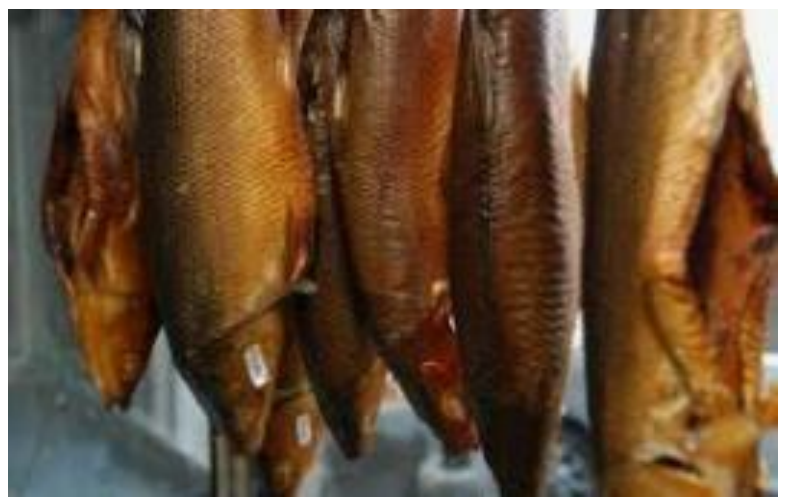

Gambar 5 Bandeng Asap

\subsection{Analisa potensi ekowisata}

Menurut Page dan Ross (2002), terdapat tiga prinsisp ekowisata yaitu meliputi konservasi, partisipasi masyarakat dan juga partisipasi masyarakat.

1. Prinsip konservasi.

a. Wisata mangrove

Medokan Ayu merupakan salah satu kelurahan di Kecamatan Rungkut yang berbatasan langsung dengan area konservasi hutan mangrove disisi sebelah Timur Surabaya. Wisata mangrove merupakan salah satu wisata alam yang lokasinya berada pada area konservasi Pemkot Surabaya. Wisata ini berusaha untuk menyajikan potensi alam dan fauna mangrove yang masih alami. Beberapa fasilitas pendukunga di wisata mangrove memanfaatkan beberapa barang bekas yang tak terpakai. Seperti bekas pipa pompa air, paving, kayu, hingga tiang PJU (Penerangan Jalan Umum) yang telah rusak. Berbagai barang bekas ini pun diubah menjadi benda-benda yang bermanfaat. Sehingga 
wisata mangrove ini merupakan salah satu representasi konsep ekowisata di Surabaya Timur yaitu dengan mengedepankan konsep pelestarian ekologi dan juga edukasi. Ekowisata di hutan mangrove merupakan salah satu upaya untuk konservasi, sehingga dapat berjalan beriringan dengan proses konservasi tersebut (Mulyadi dan Fitriani, 2012).

b. Wisata kampong hidroponik

Kampung hidroponik merupakan salah satu kampong produktif yang mengoptimalkan pertanian hidroponik yang dilakukan oleh warga. Wujud konservasi yang dilakukan oleh warga yaitu budaya untuk menanam hidroponik. Kebiasaan yang dilakukan oleh warga akan memberikan dampak positif kepada lingkungan dan juga perekonomian warga. Hidup sehat karena memanfaatkan sayur dan buah dari hasil menanam sendiri.

c. Wisata bandeng

Sama halnya dengan kampong hidroponik bentuk konservasi pada wisata bandeng yaitu budaya dalam memberdayakan bandeng pada habitat alaminya sehingga menghasilkan kualitas bandeng yang enak dan menjadi ciri khas kawasan tersebut. Sedangkan kuliner bandeng Medokan Ayu juga menjadi ciri khas yang dihasilkan dari tradisi mereka dalam mempertahankan cara mengolah dan memasaknya. Potensi tersebut dapat menghasilkan keuntungan dari aspek ekonomi sekaligus menjadi identitas kawasan.

\section{Prinsip Partisipasi Masyarakat.}

Berdasarkan ketiga wisata di Medokan Ayu partisipasi masyarakat sangat diperlukan karena potensi tersebut menjadi ujung tombak dalam mengembangkan ekowisata.

\section{- Wisata Mangrove}

Pengelolaan wisata mangrove ini masih didominasi oleh Pemkot Surabaya karena merupakan area konservasi dimana flora dan faunanya dilindungi oleh negara. Sehingga partisipasi masyarakat masih minim dalam pengelolaanya. Meskipun dalam wisata mangrove terdapat tambak yang dimiliki oleh warga dalam waktu dekat akan dikelola oleh Pemkot karena masuk dalam area konservasi.
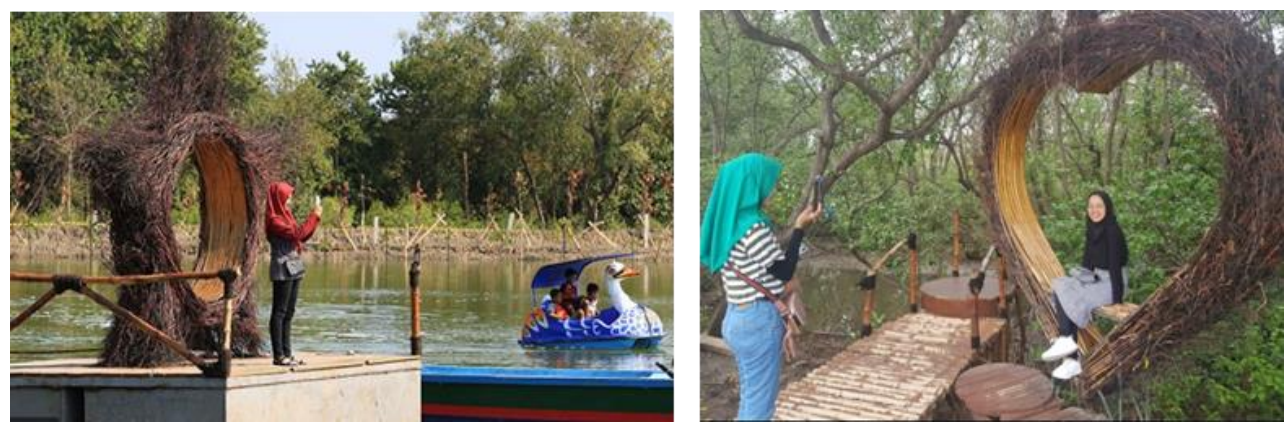

Gambar 6 Wisata Mangrove Medokan Ayu

- Wisata kampung hidroponik

Kampung hidroponik merupakan kampung yang sebagian besar warganya menjadi petani hidroponik. Diawali dari hobi yang kemudian mendapatkan income bagi warga.Kampung hidroponik ini seluruhnya dikelola oleh warga bekerjasama dengan bank swasta dalam pengembangannya. Dan selanjutnya Pemkot Surabaya akan turun tangan untuk membantu mengembangkan kampung hidroponik tersebut. Partisipasi warga tidak hanya dalam kegiatan bertani melainkan juga dalam pengelolaannya sehingga dapat mendatangkan keuntungan bagi warga juga.

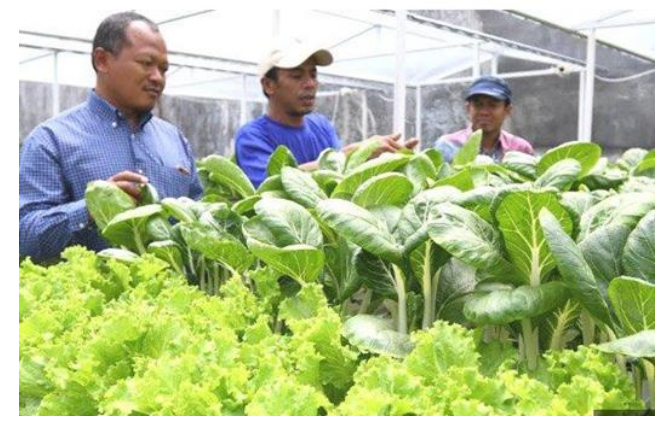

Gambar 7 Kampung Hidroponik 
- Wisata bandeng

Bandeng menjadi salah satu produk unggulan Medokan Ayu. Dimana pada saat ini pengelolaan bandeng sampai dengan hasil olahannya di lakukan oleh warga. Sehingga pengembangan wisata ini akan sangat menguntungkan warga Medokan Ayu.

\section{Prinsip Ekonomi.}

Yang menjadi perhatian dalam prinsip ekonomi ekowisata yaitu bahwa wisata nantinya dapat memberikan nilai ekonomi bagi kesejahteraan masyarakat. Apabila dilihat prinsip ekonomi maka wisata kampong hidroponik dan wisata bandeng lebih memberikan nilai ekonomi yang merata bagi masyarakat karena pengelolaannya murni dilakukan oleh masyarakat sendiri. Sedangkan wisata mangrove sudah ditangani oleh Pemkot Surabaya karena merupakan kawasan konservasi sehingga tidak memberikan keuntungan ekonomi bagi warga masyarakat tetapi memberikan pendapatan bagi Pemkot Surabaya. Karena pengelolaan sudah ditangani oleh Pemkot Surabaya.

\subsection{Analisis SWOT}

Analisis potensi ekowisata di Kelurahan Medokan Ayu dilakukan menggunakan analisa SWOT. Analisa SWOT (Strength, Weaknesses, Opportunities, Threat) merupakan proses analisis yang ditekankan pada aspek tangible dan intangible di kelurahan Medokan Ayu.

\section{Kekuatan (Strengths)}

1. Wilayah Kelurahan Medokan Ayu memiliki kelebihan yaitu memiliki keberagaman kondisi geografis terdiri dari tambak, sungai, permukiman dan juga area pesisir. Kawasan tersebut mempunyai fungsi sebagai area konservasi dan penyangga kawasan yang ada disekitarnya.

2. Kekayaan alam di Medokan ayu cukup banyak terutama pada area pesisir. Keanekaragaman flora dan fauna dapat ditemui karena pelestarian maih terjaga. Selain potensi alam, budaya yang dimiliki oleh Kelurahan Medokan Ayu juga beragam seperti: budaya kuliner (bandeng asap Medokan Ayu).

3. Terdapat nilai-nilai lokalitas yang dilestarikan dari wisata di Medokan Ayu yaitu kuliner bandeng yang menjadi ciri khas di Surabaya.

4. Keterlibatan beberapa pengampu kepentingan (stakeholder) terutama warga RW XII Kelurahan Medokan Ayu, Pemkot Surabaya dan juga Yayasan Danamon Peduli Lingkungan.

5. Sarana dan prasarana di Kelurahan Medokan Ayu yang cukup lengkap sehingga apabila dikembangkan menjadi lokasi wisata maka sangat cocok. Berdekatan dengan Jalur poros yang menghubungkan Surabaya Utara sampai dengan Surabaya Selatan (MERR) dan juga dekat rencana jalur lingkar Timur (OER)

\section{Kelemahan (Weaknesses)}

1. Ekowisata merupakan salah satu konsep wisata yang masih terbilang baru, sehingga pengelolaan ekowisata belum optimal karena keterbatasan informasi dan pengetahuan yang diniliki oleh pengelola masih minim.

2. Ketersediaan sarana dan prasaran kurang memadai (Akses jalan yang masih belum ada perkerasan) dan fasilitas dan pelayanan umum masih sangat minim.

3. Keterlibatan para pihak seperti Pemkot Surabaya, Program CSR dan Masyarakat dalam perencanaan ekowisata belum terintegrasi

4. Minimnya kegiatan promosi, selama ini hanya melalui website belum terintegrasi dengan tujuan wisata di Surabaya lainnya.

Peluang (Opporutnities)

1. Keinginan masyarakat untuk mengembangkan konsep ekowisata cukup besar dan didukung stakeholders seperti Program CSR, Pemerintah Kota dan Institusi pendidikan.

2. Peluang peningkatan perekonomian warga setempat dan juga pendapatan daerah.

3. Munculnya kuliner asli masyarakat Medokan Ayu

\section{Ancaman (Threats)}

1. Pola perilaku pengunjung mangrove yang sulit untuk dikontrol sehingga semakin mudah mangrove tercemar.

2. Terjadinya penebangan liar mangrove yang dilakukan oleh masyarakat sehingga berdampak pada kondisi kawasan hutan mangrove disekitarnya.

3. Terkikisnya nilai-nilai budaya local (kuliner asli) karena masuknya budaya asing

Berdasarkan hasil Analisa SWOT apabila dikaitkan dengan aspek-aspek pendukung keberlanjutan kota yang meliputi: 
a. Media Sosial

b. Kebijakan publik

c. Pengembangan Bisnis dan ekonomi

d. Pendidikan

e. Masyarakat dan

f. Gaya hidup

Keenam indikator tersebut secara umum dikelompokkan kepada tiga aspek yaitu sosial budaya, ekonomi dan lingkungan. Berdasar hasil analisis SWOT, maka Ekowisata di Medokan Ayu memiliki potensi dan permasalahan meliputi aspek lingkungan (Potensi ekowisata, keberagaman flora dan fauna), sosial budaya (budaya kuliner produk olahan bandeng) dan ekonomi (Masyarakat mengembangkan potensi wilayah (hidroponik dan tambak bandeng) yang dapat mengembangkan keuntungan ekonomi, Kerjasama dengan pihak swasta dan pemerintah untuk mengembangkan wisata tersebut).

\subsection{Analisa SO, ST, WO dan ST}

Strategi SO, ST, WO dan WT yang bisa dilakukan Kelurahan Medokan Ayu untuk mendukung keberlanjutan kota yaitu:

1. Strategi SO

a. Lingkungan (Aspek lingkungan menjadi point penting yang perlu dikembangkan sekaligus dijaga. Lingkungan di Medokan Ayu berhubungan erat dengan pengelolaan wisata hidroponik dan wisata mangrove)

b. Sosial dan budaya (Aspek budaya berupa budaya kuliner asli Medokan Ayu yaitu olahan bandeng.

c. Ekonomi (Kerjasama dengan pihak stakeholder dan pemerintah untuk mengembangkan wisata di Medokan Ayu dan memperbaiki sarana dan prasarana pendukung ekowisata)

2. Strategi ST

a. Sosial dan budaya (Mempromosikan kuliner asli Medokan Ayu yaitu bandeng sehingga dikenal oleh masyarakat)

b. Lingkungan (Memberikan edukasi terhadap pengunjung dan masyarakat tentang pentingnya menjaga lingkungan sehingga flora dan fauna tetap terjaga)

3. Strategi WO

a. Melakukan promosi sehingga mudah dikenal dan mampu memperkuat brand name Medokan Ayu sehinngga menjaga keaslian kuliner Bandeng Medokan Ayu, hidroponik dan wisata mangrove. Ajang promosi tersebut dapat mendatangkan banyak wisatawan, sehingga dapat meningkatkan perekonomian masyarakat.

b. Memperkuat kerjasama dengan pihak luar (stakehorder dan pemerintah) sehingga dapat mendukung untuk meningkatkan kualitas sarana dan prasarana pendukung ekowisata

4. Strategi WT

a. Memanfaatkan perkembangan teknologi internet dengan menggunakan media sosial sebagai ajang promosi dan informasi (memperkenalkan kuliner asli bandeng Medokan Ayu, wisata hidroponik dan wisata mangrove)

b. Memperkuat kerjasama dengan pihak luar (stakehorder dan pemerintah) sehingga dapat memperbaiki sarana dan prasarana pendukung ekowisata.

\section{Kesimpulan}

Potensi ekowisata Kelurahan Medokan Ayu yang terdiri potensi budaya (kuliner dan bertani) dan parorama alam (Flora dan fauna) memiliki daya tarik untuk pengembangan ekowisata di Surabaya. Berdasarkan hasil analisa maka ekowisata di Medokan Ayu dapat dikembangkan dengan mengoptimalkan aspek SO. Potensi lingkungan (keberagaman flora dan fauna), sosial budaya (budaya kuliner olahan bandeng) dan ekonomi yang dimiliki oleh kelurahan Medokan Ayu dikembangkan oleh masyarakat bekerjasama dengan pemerintah serta program CSR. Permasalahan yang dihadapi berupa WT dapat diselesaikan dengan cara mengoptimalkan strategi SO. Apabila sudah terintegrasi dengan baik aspek lingkungan, ekonomi dan social budaya otomastis akan mendukung keberlanjutan Kota Surabaya.

\section{Ucapan Terima Kasih}

Ucapan terima kasih kepada Progdi Arsitektur UPN"Veteran" Jawa Timur dan Laboratorium perancangan kawasan dan bangunan arsitektur Progdi Arsitektur. 


\section{Daftar Pustaka}

Atmoko, Wisnu Dwi. (2008). Studi Prospek Pengembangan Ekowisata pada Kawasan Sekitar Kars Gombong Selatan dalam Mendukung Keberlanjutan Wilayah, Skripsi, Universitas Diponegoro

Yoeti, Oka A. (1997). Perencanaan dan Pengembangan Pariwisata, Jakarta: Pradnya Paramita

Page, S.J., dan Ross, D.K. (2002). Ecoutorism Pearson Education Limited, China

Mulyani, E., dan Fitriani, N. (2002). Konservasi Hutan Mangrove Sebagai Ekowisata, Jurnal Ilmiah Teknik Lingkungan Rangkuti. (2013). Analisis SWOT Teknik Membedah Kasus Bisnis, Jakarta: Gramedia

Soegianto, A. (2007). Ekologi Kuantitatif. Usaha nasional, Surabaya

Sugiyono. (2009). Metode Penelitian Kuantitatif, Kualitatif dan R\&K, Bandung: Alphabeta

Suprayitno. (2008) Teknik Pemanfaatan Jasa Lingkungan dan Wisata Alam, Bogor; Departemen Kehutanan Pusat Diklat Kehutanan

\section{Pustaka Internet}

Cak Sur, (2011). Dongkrak Pamor Bandeng, https://surabaya.tribunnews.com/2011/03/30/dongkrak-pamor-bandeng (diakses tanggal 5 September 2020) 